JAN TEGOWSKI

(Białystok)

\title{
Wprowadzanie w życie postanowień aktu krewskiego w latach 1385-1399
}

\section{Realisierung der Vertragsbeschlüsse von Krewa 1385-1399}

1. Zakwestionowanie unii krewskiej $w$ historiografii. 2. Przebieg rokowań. 3. Realizacja postanowień krewskich. 4. Regni Poloniae perpetuo applicare - praktyka. 5. Przywracanie litewskiej odrębności. 6. Wnioski.

1. Bestreiten der Union von Krewa in der Geschichtsforschung. 2. Verlauf der Verhandlungen. 3. Realisierung der Beschlüsse von Krewa. 4. Regni Poloniae perpetuo applicare - Ausführung. 5. Wiederherstellung der litauischen Separation. 6. Schlussfolgerungen.

Od chwili publikacji aktu krewskiego przed ponad półtorawieczem przez Michała Wiszniewskiego ${ }^{1}$ treść tego dokumentu jest przedmiotem wzmożonych zainteresowań wielu historyków, którzy starają się zgłębić istotę unii Polski z Litwą zaprojektowanej w tym akcie. Nie znaczy to jednak, że wcześniej nie znano tego dokumentu. Jak zauważyła to Jūrate Kiaupiené, akt ten dobrze znany był już żyjącemu i tworzącemu w wieku XVIII Adamowi Naruszewiczowi ${ }^{2}$. Wspomniana uczona litewska stoi jednak na stanowisku, że dokument krewski nie był aktem unii obu państw, lecz jedynie umową przedmałżeńską ${ }^{3}$. I to jest bezpośrednim impulsem do napisania niniejszego przyczynku.

Daty limitujące zakres chronologiczny moich krótkich rozważań to: $z$ jednej strony - początek pertraktacji polsko-litewskich i wystawienie samego dokumentu krewskiego, a z drugiej - śmierć królowej Jadwigi oraz klęska Witolda nad Worsklą, która miała wpływ na regres tendencji separatystycznych Wielkiego Księstwa Litewskiego.

\footnotetext{
${ }^{1}$ M. W iszniewski, Pomniki historii i literatury polskiej, t. IV, Kraków 1837, s. 92.

2 J. K i a u pien é, Akt krewski z 14 sierpnia 1385 r.: gdzie kryje sie problem - $w$ dokumencie, czy $w$ jego interpretacjach?, KH 2001, $\mathrm{nr} 108$, z. 4, s. 47-62.

${ }^{3}$ Ibidem, s. 52.
} 
Zreferowanie obszernej literatury przedmiotu prezentującej różne interpretacje dokumentu Jagielly z 14 VIII 1385 r. nadawałoby się na odrębną publikację, w związku $\mathrm{z}$ czym ograniczę się $w$ mej pracy jedynie do najważniejszych pozycji. Omówienie najważniejszych poglądów historyków polskich $i$ litewskich $w$ tej sprawie można znaleźć $w$ ostatnio przełożonej na język polski książce $M$. Jučasa ${ }^{4}$, zaś analizę dyplomatyczno-paleograficzną aktu - w artykule M. Koczerskiej ${ }^{5}$.

Szczególnym zainteresowaniem historyków cieszył się punkt mówiący o przyłączeniu Wielkiego Księstwa Litewskiego do Korony Królestwa Polskiego (coronae regni Poloniae perpetuo applicare), bo on faktycznie stanowil o unii obu państw. Nie zawsze badacze oddzielali program przedsięwzięcia od praktycznych prób i moźliwości jego wprowadzenia w życie. W badaniach nad genezą $\mathrm{i}$ funkcją dokumentu początkującego unię nie można tracić $\mathrm{z}$ oczu calości jego postanowień, których realizacja warunkowała istnienie unii Polski z Litwą $\mathrm{w}$ ostatnim piętnastoleciu XIV w. Właśnie ten aspekt stanowić będzie przedmiot moich uwag na temat początków unii polsko-litewskiej. Nie będziemy wnikać w kwestie tradycji aktu krewskiego w świadomości kolejnych pokoleń Polaków i Litwinów, lecz zajmiemy się sprawą wprowadzania w życie jego treści w najbliższym czasie po jego wystawieniu. To pozwoli odpowiedzieć na pytanie, czy praktyka funkcjonowania unii obu państw oparta była na znajomości wspomnianego dokumentu, czy też nie.

W pracy poświęconej genezie unii Polski z Litwą, która ukazała się przed ponad dziesięciu laty, miałem sposobność wykazać, że inicjatorem $\mathrm{w}$ tej sprawie była strona litewska ${ }^{6}$. Nie stoi $\mathrm{z}$ tym poglądem $\mathrm{w}$ sprzeczności wiadomość zawarta w mowie Mikołaja Lasockiego na Soborze w Bazylei, iż po śmierci Ludwika Węgierskiego, który był królem Polski i Węgier, tron polski przypadł jednej z jego dwóch córek, a panowie polscy postanowili zaproponować wraz z jej ręką tron polski wielkiemu księciu litewskiemu:

Miserunt solempnes ambasiatores ad regem nunc mortuum [tj. do Jagielly - przyp. J. T.], qui tunc fuit dominus et magnus dux illius patrie, ut si vellet fidem catholicam cum tota sua gente suscipere et illam patriam incorporare regno...

${ }^{4}$ M. J u čas, Unia polsko-litewska, trum. A. Firewicz, Toruń 2003.

${ }^{5}$ M. Koczersk a, Autentyczność dokumentu unii krewskiej 1385 roku, KH 1992, nr 99, z. 1, s. $59-78$.

${ }^{6} \mathrm{~J}$. Tęgowski, Bezkrólewie po śmierci Ludwika Wegierskiego a geneza unii Polski z Litwq, [w:] Studia historyczne z XIII-XV wieku, red. J. Sliwiński, Olsztyn 1995, s. 87-110.

7 Eine polnische Denkschrift auf dem Konzil in Basel, wyd. K. Forsteuter, H. Koeppen, Zeitschrift für Ostforschung 1972, 21, s. 693-696. 
Mistrz Mikołaj Lasocki nie wnikał w szczegóły historyczne i po prostu pominąl w swej mowie fakt koronacji Jadwigi na króla Polski oraz informację o poselstwie litewskim, które zjawiło się w Krakowie 18 I 1385 r., redukując swą wypowiedź do najważniejszego w jego mniemaniu faktu, którym było zjawienie się posłów polskich w Krewie, gdzie wielki książę litewski Jagiełło wystawił 14 VIII 1385 r. akt zgody na warunki postawione mu wcześniej. Niektóre z nich zaproponował sam wielki książę litewski, niektóre zaś królowa Elżbieta Bośniaczka i polscy panowie. Niektóre z tych punktów byly do wykonania w krótkim czasie, inne zaś musiały być realizowane w dłuższym okresie. Do tych proponowanych przez stronę litewską można zaliczyć przyjęcie chrztu, którą to propozycję posłowie litewscy przedstawili matce królowej Jadwigi w tych slowach:

Dum autem ea, ut praeferuntur, fine terminabuntur ordinato, interdum dominus Jagalo magnus dux cum omnibus fratribus suis nondum baptisatis, proximis, nobilibus, terrigenis majoribus et minimis, in suis terris existentibus, fidem katholicam sanctae ecclesiae Romanae nititur, cupit et desiderat amplexari. ${ }^{8}$

$\mathrm{Z}$ tą propozycją wiąże się postulat Jagiełly dotyczący jego małżeństwa z Jadwigą. Warunkiem postawionym przez królową Elżbietę Bośniaczkę jest niewątpliwie wymóg zaspokojenia roszczeń Wilhelma Habsburga wynikających z wcześniejszych umów króla Ludwika $\mathrm{z}$ Leopoldem III, a mianowicie wypłacenia mu 200 tys. florenów odszkodowania'. Ten warunek mógł zostać wykonany w stosunkowo krótkim czasie, lecz z powodu odmowy ze strony Wilhelma nie został nigdy dopełniony. Zapewne też i punkt dotyczący użycia całego skarbu wielkiego księcia dla odzyskania wszystkich szkód, które poniosło zarówno Królestwo Polskie, jak i Litwa, zostal postawiony przez stronę polsko-węgierską. Z tym warunkiem wiąże się kolejny, w którym Jagiełlo mial się zobowiązać do odzyskania i przywrócenia Królestwu Polskiemu wszystkich utraconych ziem, jakie kiedykolwiek zostały od niego oderwane. Kolejny, piąty, punkt dotyczy przywrócenia przez wielkiego księcia wolności wszystkim jeńcom chrześcijańskim, a szczególnie pochodzącym z ziem polskich. Jest to z całą pewnością warunek postawiony przez stronę polską. Ostatnim, szóstym, punktem umowy krewskiej jest przylączenie wszystkich ziem posiadanych przez wielkiego księcia Jagiełłę do Korony Królestwa Polskiego. Z całą pewnością ten ostatni punkt umowy zostal postawiony przez panów polskich. Nie był to łatwy warunek dla strony litewskiej. Gdy jednak zważymy, iż całe przedsięwzięcie unii Polski z Litwą miało uchronić Litwę od krucjat organizowanych przez zakon krzyżacki, to wcielenie tego kraju do chrześcijańskiego państwa, jako część

" Akta unii Polski z Litwq 1385-1791, wyd. S. Kutrzeba, W. Semkowicz [cyt. dalej AU], Kraków 1932, nr 1, s. 1-3.

${ }^{9}$ Ks. B. Pr zyb y s zew ski, Jadwiga $i$ Wilhelm, Analecta Cracoviensia 1975, t. VII, s. 120-122. 
Korony Królestwa Polskiego, stanowić mogło jego ochronę prawną przed krucjatami organizowanymi przez zakon krzyżacki. Ten cel mógl zostać osiągnięty jedynie $\mathrm{w}$ połączeniu $\mathrm{z}$ przyjęciem chrztu $\mathrm{w}$ obrządku zachodnim nie tylko książąt, panów i bojarów, lecz także pospolitego spoleczeństwa Litwy ${ }^{10}$.

Akt krewski nie zawierał postulatu gwarancji uzyskania przez Jagiełle korony polskiej po poślubieniu Jadwigi. Ten mankament znalazł uzupełnienie $\mathrm{w}$ dokumencie wolkowyskim $\mathrm{w}$ początku $1386 \mathrm{r}$. wystawionym przez przedstawicieli polskiego możnowladztwa ${ }^{11}$. Otóż znani $\mathrm{z}$ aktu krewskiego panowie małopolscy Wlodek z Charbinowic, Mikołaj Bogoria oraz Krystyn z Ostrowa, którym towarzyszył jeszcze podstoli krakowski Piotr Szafraniec, zapewnili Jagiełłe o powszechnej zgodzie na jego małżeństwo z królową Jadwiga oraz o planowanym wiecu generalnym zwołanym do Lublina na najbliższe święto Matki Boskiej Gromnicznej (2 II 1386 r.), na którym wielki książę litewski miał być zatwierdzony na przyszłego władcę Królestwa Polskiego. Na ten wiec zaproszono Jagiełłę oraz jego braci, książąt i doradców. W żadnym $z$ tych dwóch dokumentów nie wspomniano o gwarancjach zabezpieczających wykonanie ich postanowien. Zapewne problem ten wynikną na wiecu w Lublinie, o którym, prócz wzmianki we wspomnianym dokumencie wołkowyskim, nic nie wiemy. Tam zapewne, jeśli wiec się odbył, postanowiono zastosować załogę wobec najbliższych krewnych wielkiego księcia litewskiego ${ }^{12}$.

Pierwsze $\mathrm{z}$ postanowień zawartych $\mathrm{w}$ akcie krewskim realizowane było w kilku etapach. Chrzest Jagielly i jego krewnych nastąpił w Krakowie w lutym 1386 r., o czym informują nas współczesne źródła. Jak już wcześniej o tym pisałem, w Krakowie oprócz Jagiełly zostal ochrzczony jeszcze jego brat Wigunt oraz po raz już trzeci chrzest przyjął stryjeczny brat wielkiego księcia Witold. W stolicy Polski nie zjawił się Korygiełło, jak też zapewne i najmłodszy $z$ braci wielkiego księcia Świdrygiełło, bowiem ich imiona nie zostały wymienione we współczesnych owym wydarzeniom źródłach - zapisce w Kalendarzu Katedry Krakowskiej oraz Spominkach Gnieźnieńskich ${ }^{13}$. Nie zachował się żaden ślad obecności w Krakowie Korygiełly, który w tym

${ }^{10}$ S. M. K u czyński (Wladyslaw Jagiello ok. 1351-1434, wyd. II, Warszawa 1987, s. 58) sądzi, że było to zabezpieczenie przed roszczeniami terytorialnymi zakonu krzyżackiego, któremu ziemie litewskie i ruskie nadał cesarz Ludwik Wittelsbach.

$" \mathrm{AU}, \mathrm{nr} 2$, s. 3-4; S. Szczur, Negocjatorzy unii Polski z Litwa, Analecta Cracoviensia 1987 , t. XIX, s. 181-205.

${ }^{12} \mathrm{AU}, \mathrm{nr} 3,4,5,6$, s. 4-6.

${ }_{13}$ Pomniki dziejowe Polski, ser. II, t. V, wyd. Z. Kozlowska-Budkowa, Warszawa 1978, s. 125; t. VI, wyd. B. Kürbis, Warszawa 1962, s. 100. 
czasie był na tyle dorosły, by dowodzić obroną Mścisławia ${ }^{14}$. Trzech innych rodzonych braci Jagielly, a mianowicie Skirgiełlo, Korybut i Lingwen, wcześniej przyjęło chrzest prawosławny ${ }^{15}$. W następnym roku dokonano masowego chrztu Litwinów. Jak powiada Mikołaj Lasocki, prałaci i doktorzy przybyli na Litwę z Królestwa Polskiego w ciągu jednego roku ochrzcili 400 tys. osób. Liczba ta nie jest z pewnością precyzyjna, bowiem nie mamy pewności, że wszyscy Litwini ochrzcili się od razu. $Z$ całą pewnością na chrzest w $1387 \mathrm{r}$. nie zgodziła się ludność Żmudzi, a część Litwinów już wyznawała prawosławie. Chrystianizacja Żmudzinów nastąpiła dopiero na początku następnego stulecia $^{16}$. Tym niemniej - jak powiada Jan Długosz - sam król bardzo zaangażował się w proces chrystianizacji swego kraju, nauczając swój lud prawd wiary $w$ języku litewskim ${ }^{17}$.

Mimo to zakon krzyżacki w Prusach oskarżal Litwinów o pozorowane przyjmowanie chrztu, a królową Jadwigę o cudzołóstwo. Znamiennym tego przykładem jest obrona krzyżacka przed zarzutami Polaków na Soborze w Konstancji, gdzie twierdzili oni, iż wielu chrzciło się wskutek pokusy otrzymania białych szat, po które katechumeni zgłaszali się po kilkakroć. Papież Urban VI wysłał swego wysłannika, by zbadał całą sprawę, i efektem tego była bulla z 30 XII 1387 r. wystosowana do książąt mazowieckich i panów polskich oraz z 17 III $1388 r^{18}{ }^{18}$, w której nazwal nowego króla Polski princeps christianissimus. Kolejny papież rzymski - Bonifacy IX, już 10 listopada mianował swoim wysłannikiem do królestw Węgier i Polski swego rodaka - kanonika neapolitańskiego Jana Manco, który w maju następnego roku $\mathrm{w}$ towarzystwie Ludwika - rycerza $\mathrm{z}$ Neapolu, udał się do państw Jagiełły, pragnąc zaprowadzić pokój między królem a krzyżakami. Posłowie ci, zabiegając o pokój między zwaśnionymi stronami, tak oto relacjonowali stan chrystianizacji Litwy wielkiemu mistrzowi krzyżackiemu:

...quatenus cum domino Wladislao rege Polonie et aliis Litwanis noviter baptizatis, prout in partibus Litwanie de mandato ipsius domini nostri [tj. papieża - przyp.

${ }_{14}$ Woskriesenskaja letopis', [w:] Polnoje sobranije russkich letopisej, t. 8, S. Peterburg 1859, s. 51.

15 J. T ̨ g ow ski, Pierwsze pokolenia Giedyminowiczów, Poznań-Wroctaw 1999, s. 146; t e nże, Data urodzenia Jagielly oraz data chrztu jego starszych braci, Genealogia. Studia i Materiały Historyczne 2003, t. 15, s. 137-144.

${ }^{16}$ S. Zaj ąc zk ow ski, Żmudź w poczq̨tkach Unji polsko-litewskiej, [w:] Pamiętnik V Powszechnego Zjazdu Historyków Polskich w Warszawie, t. 1, Lwów 1930, s. 337-344; Ks. M. B a n a s z a k, Chrzest Żmudzi i jego reperkusje w Konstancji, [w:] Chrzest Litwy. Geneza, przebieg, konsekwencje, red. ks. M. T. Zahajkiewicz, Lublin 1990, s. 57-90.

${ }^{17}$ Joannis Dlugossi Annales seu Cronicae incliti Regni Poloniae, lib. 10, Varsoviae 1985, s. 160; J. Fijałek, Uchrześcijanienie Litwy przez Polske $i$ zachowanie w niej jezyka ludu, [w:] Polska i Litwa w dziejowym stosunku, Kraków 1914, s. 57-58; W. A b ra h a m, Polska a chrzest Litwy, [w:] Polska i Litwa w dziejowym stosunku, s. 20; J. O c h m a ń s k i, Biskupstwo wileńskie w średniowieczu, Poznań 1972, s. 8-9.

${ }^{18}$ L. D a vid, Preussische Cronik, t. 7, Königsberg 1815, s. 201-203; KDKW, nr 12, s. 22-24. 
J. T.] ea vera informacione percepimus et oculis propriis vidimus plures erectas ecclesias necnon episcopum Wilnensem per ipsam civitatem Wilne processionaliter incedentem, quem sequebatur dictus dominus rex et aliorum Litwanorum baptizatorum maxima multitudo... ${ }^{19}$

W innym dokumencie, wystawionym $13 \mathrm{~V} 1390 \mathrm{r}$. w Wilnie, ci sami wysłańcy papiescy informują o fundacji katedry wileńskiej na chwałe Św. Trójcy, Matki Bożej i św. Stanisława oraz licznych kościolów parafialnych, a także król ten omnes homines Lithuanorum nobiles et populares utriusque sexus in nomine Patris et Filii et Spiriti Sancti baptisari procuravit, prout consideramus et considerare potuimus ${ }^{20}$.

Następstwem przyjęcia chrześcijaństwa zachodniego przez wielkiego księcia Jagiełłę i jego poddanych było powstanie struktury kościelnej, a więc nie tylko wzniesienie nowych świątyń, lecz przede wszystkim powołanie diecezji oraz sieci parafialnej. Gdy porównamy chrzest Litwy do chrztu Polski, możemy zauważyć istotną różnicę między tymi wydarzeniami. W Polsce Mieszka I powołano biskupstwo misyjne niepodlegające żadnej $\mathrm{z}$ istniejących w pobliżu metropolii, natomiast biskupstwo wileńskie powołane do życia w 1387 r., aczkolwiek bulla papieża Urbana VI w tej sprawie wystawiona jest 12 III $1388 \mathrm{r}^{21}$, od początku było częścią prowincji gnieźnieńskiej. To wskazuje na zamysł rzeczywistego włączenia Wielkiego Księstwa Litewskiego w skład szeroko pojmowanej Korony Królestwa Polskiego, co wcale nie oznacza zniesienia jego odrębności państwowej. Przykładem podobnego charakteru zależności od Korony Królestwa Polskiego jest Mołdawia, która stała się lennem Królestwa Polskiego we wrześniu 1387 r.

Odrębną sprawą była Żmudź, która nie została objęta chrystianizacją razem $\mathrm{z}$ Litwą właściwą. Prawdopodobnie kraina ta nie była $w$ takim stopniu zależna od władzy wielkiego księcia litewskiego, jak pozostałe ziemie. Stąd też kilkukrotne odstępowanie Żmudzi przez Jagielłę i Witolda zakonowi krzyżackiemu w latach 1382-1404 miało na celu nie tyle rzeczywiste pozbywanie się tej ziemi, ile wymuszenie bliższego jej związku z Wielkim Księstwem Litewskim. Dlatego wlaśnie o Żmudzi nie ma mowy ani w akcie krewskim, ani też innych aktach z XIV w. dotyczących unii.

${ }^{19}$ Codex epistolariis Vitoldi magni ducis Lithuaniae 1376-1430, wyd. A. Prochaska, Kraków 1882 [cyt. dalej CEV], nr 65, s. 22.

${ }^{20}$ Biblioteka Kórnicka PAN, rkps 203, s. 150-153; dokument ten jest aneksem do innej mojej publikacji, która jest w druku.

${ }^{21}$ Kodeks dyplomatyczny katedry i diecezji wileńskiej [cyt. dalej KDKW], t. I, wyd. ks. J. Fijałek, W. Semkowicz, Kraków 1948, nr 1-3, s. 1-10, nr 10, s. 20-22. O przynależności diecezji wileńskiej do prowincji gnieźnieńskiej świadczy udział biskupów wileńskich w synodach prowincjonalnych (zob. H. Lik owski, Synod prowincjonalny kaliski $z$ r. 1406, Przegl. Teolog., [Lwów] 1925, R. VI, s. 389; KDKW, nr 78, s. 107-108: synod wieluński z 1420 r.). 
Drugi z wymienionych przeze mnie punktów aktu krewskiego, chociaż $\mathrm{w}$ dokumencie jest wymieniony jako trzeci $w$ kolejności - zapłacenie odszkodowania Wilhelmowi Habsburgowi w kwocie 200 tys. florenów - nie miał szansy wejść $\mathrm{w}$ życie, bowiem książę austriacki nigdy nie pogodził się $\mathrm{z}$ faktem, że Jadwiga Andegaweńska odwołała swoje wcześniejsze $\mathrm{z}$ nim zaślubiny. Obstawał przy ważności swych zaślubin z Jadwigą w Heimburgu w 1378 r., mimo uznania ich za nieważne przez Kościól ${ }^{22}$. Pozostał w stanie bezżennym aż do śmierci Jadwigi i nie pogodził się z jej zamążpójściem za Litwina, co oszczędziło Jagielle wydatkowania tak znacznej kwoty pieniędzy. Ten brak zgody ze strony Wilhelma i nieprzyjęcie pieniędzy $\mathrm{z}$ tytułu odszkodowania miało jednak swoje negatywne konsekwencje propagandowe na terenie Europy Zachodniej.

O realizacji trzeciego z punktów - czyli przeznaczeniu wszystkich swoich skarbów na użytek odzyskania strat, które kiedykolwiek poniosła zarówno Polska, jak i Litwa - trudno cokolwiek powiedzieć, bowiem nie mamy o tym jakichś bezpośrednich informacji, toteż rozpatrywać go będziemy razem $\mathrm{z}$ następnym, w którym Jagiełlo obiecuje własnym kosztem i staraniem przywrócić Królestwu Polskiemu wszystkie ziemie przez nie utracone. W sprawie realizacji tego punktu mamy wiele informacji; mialem okazję wielokrotnie o tym pisać. Najpierw - jeszcze w 1385 r. - jak nas informują książęta mazowieccy w skardze z 1426 r., Jagiełło wraz z innymi książętami litewskimi wezwał na Litwę Siemowita IV, który w tym czasie okupował ziemię lęczycką i Kujawy brzeskie, i obiecal pisemnie nadać mu ziemie ruskie w zamian za zrzeczenie się tych ziem na rzecz królowej Jadwigi ${ }^{23}$. Wtedy też prawdopodobnie doszło do umowy w sprawie małżeństwa Piasta mazowieckiego z Aleksandrą siostrą Jagielly. Siemowit IV już 12 grudnia w Krakowie zawarł ugodę z Królestwem Polskim, zrzekając się od razu ziemi łęczyckiej i skrawków Wielkopolski, zaś Kujawy brzeskie przyrzekł zwrócić w momencie wypłaty 10 tys. grzywien srebra.

Jeśli chodzi o dalsze straty terytorialne poniesione przez Królestwo Polskie, to ich rewindykacja zajęla Jagielle wiele sił i środków. Kujawy inowroclawskie, ziemię dobrzyńską oraz wieluńską posiadał od lat Władysław Opolczyk. Podobnie jak z Siemowitem, Jagiełło postanowił odzyskiwać te ziemie $\mathrm{z}$ rąk Piasta opolskiego drogą pokojową. Dlatego właśnie król Władysław zaproponował swemu imiennikowi malżeństwo swego rodzonego brata Wigunta Aleksandra z księżniczką Jadwigą - córką Opolczyka, mając nadzieję poprzez

${ }^{22}$ A. F. G r a b ski, Jadwiga-Wilhelm-Jagiello w opiniach europejskich, Nasza Przeszłość 1966, nr 23 , s. 126

${ }^{23}$ Articuli Vladislai regi Poloniae a ducibus Masoviae traditi A.D. 1426 et 1428, wyd. W. Kętrzyński, [w:] Pomniki Dziejowe Polski, t. VI, Lwów 1893, s. 631-633; Kodeks dyplomatyczny Polski, t. II, nr 532; J. T \& gow ski, Sprawa ruska w stosunkach Siemowita IV z Wladyslawem Jagiellq, Prace Nauk. Wyż. Szkoły Pedagog. w Częstochowie 1994, t. II, s. 115-127. 
brata na odzyskanie przynajmniej północnych ziem Królestwa ${ }^{24}$. Udało się to jedynie częściowo, bowiem Wladysław Opolczyk powierzył swemu zięciowi tylko Kujawy inowroclawskie z Inowroclawiem, Bydgoszczą i Tucznem, zachowując przy sobie ziemię gniewkowską i dobrzyńską oraz zamek w Ztotorii u ujścia Drwęcy do Wisły ${ }^{25}$. W czasie długiej wojny z Piastem opolskim królowi polskiemu udało się zająć jedynie ziemię gniewkowską na północy oraz posiadłości południowe odłączone od Królestwa Polskiego w początku panowania Ludwika Węgierskiego, a mianowicie ziemię wieluńską, ostrzeszowską, skrawki ziemi sieradzkiej i krakowskiej ${ }^{26}$. Ziemię dobrzyńską i zamek w Złotorii Władysław Opolczyk zastawil Krzyżakom, a rekuperacja tych ziem nastąpiła dopiero w 1405 r. w wyniku długich starań Władysława Jagielły $^{27}$. Gdy w styczniu 1387 r. zmarła w więzieniu królowa Elżbieta Bośniaczka ${ }^{28}$, jej młodsza córka Jadwiga rozpoczęła odzyskiwanie Rusi halickiej dla Polski. Władyslaw Jagiełlo w tym czasie dokonywał chrztu swego kraju w towarzystwie biskupów, duchownych, książąt i panów. Drugą fazę akcji rozpoczętej przez królową Jadwigę podjął i zakończył Witold w sierpniu 1387 r., zdobywając gród w Haliczu ${ }^{29}$. Sprawa ruska nie była obojętna księciu Wladysławowi Opolczykowi, który chciał być gubernatorem tej krainy w imieniu króla Węgier. Przyłączenie Rusi halickiej do Polski spowodowało pogorszenie stosunków z Węgrami, nad którymi panowanie rozpoczynał właśnie Zygmunt Luksemburski. Z pewnością osobista interwencja króla już w kwietniu 1386 r., która położyła kres wojnie domowej w Wielkopolsce, jest również realizacją tego punktu umowy krewskiej ${ }^{30}$.

${ }^{24} \mathrm{~J}$. T ęg o ws ki, Malżeństwo Wigunta Olgierdowica w politycznych planach króla Wladyslawa Jagielly, Genealogia. Stud. i Mater. Hist. 1966, nr 7, s. 57-68; J. S p e rk a, Wojny Wladyslawa Jagielly $z$ księiem opolskim Wladyslawem (1391-1396), Cieszyn 2003, s. 20-23.

${ }^{25}$ Kodeks dyplomatyczny Polski, t. II, cz. 2, wyd. L. Rzyszezewski, A. Muczkowski, Warszawa 1848, nr 537; Dzieje Inowroclawia, t. I, red. M. Biskup, Warszawa 1978, s. 197-199; J. Ka rczewska, Kujawsko-dobrzyńskie wladztwo Wladyslawa Opolczyka, [w:] Wladyslaw Opolczyk jakiego nie znamy. Próba oceny w sześćsetlecie śmierci, red. A. Pobóg-Lenartowicz, Opole 2001, s. 53-59.

${ }^{26} \mathrm{~J}$. L a b e r s c h e k, Wojna króla Wladyslawa Jagielly z ksieciem opolskim Wladyslawem. Batalia o odzyskanie Olsztyna, Krzepic $i$ Wielunia w 1391 r., [w:] Almanach Częstochowy, Częstochowa 1993, s. 5-10; t e nż e, Wyprawa zbrojna króla Wladyslawa Jagielly na krakowsko-wieluńskie posiadlości księcia Wladyslawa Opolczyka w 1391 r., Społeczeństwo Polski Sredniowiecznej 6, red. S. K. Kuczyński, Warszawa 1994, s. 149-160; J. S pe r k a, Z dziejów wojen Wladyslawa Jagielly $z$ ksieciem opolskim Wladyslawem. Dzialania wojenne $w$ latach 1393-1394, [w:] Cracovia-Polonia-Europa, Kraków 1995, s. 307-321; J. P a k u $1 \mathrm{~s} \mathrm{k} \mathrm{i,} \mathrm{Jeszcze} \mathrm{o} \mathrm{zastawie} \mathrm{Zlotorii}$ $i$ ziemi dobrzyńskiej Krzyżakom przez Wladyslawa Opolczyka w latach 1391-1392, Zapiski Kujawsko-Dobrzyńskie 1995, t. 9, s. 11-30.

${ }^{27} \mathrm{~J}$. B i en i a k, Ksztaltowanie się terytorium ziemi dobrzyńskiej w średniowieczu, Zapiski Histor. 1986 , nr 51, z. 3, s. 36[448]-38[450].

${ }^{28}$ J. M a c ů rek, Dějiny Mad'arũ a uherského státu, Praha 1934, s. 96-98.

${ }^{29} \mathrm{CEV}, \mathrm{nr} 36, \mathrm{~s} .13$.

${ }^{30}$ Joannis Dlugossi Annales seu Cronicae, lib. 10, s. 157-159. 
Punkt piąty - czyli przywrócenie wolności jeńcom chrześcijańskim, szczególnie tym uprowadzonym z Polski - nie znalazł w literaturze przedmiotu szczególnego zainteresowania może dlatego, iż nie mieliśmy w tej sprawie wiadomości źródłowych. $\mathrm{O}$ wypełnieniu tego przyrzeczenia zaświadczają legaci papieża Bonifacego IX w dokumencie z 13 V 1390 r.:

Christianos captivos utriusque sexus ab olim captos et in servitute constitutos quamplurimos pristinae restituit [król Wladyslaw - przyp. J. T.] libertati et multa alia bona et pia opera intulit christianis... ${ }^{31}$

Brak zainteresowania tym zagadnieniem $w$ innych źródłach jest może spowodowany tym, iż - jak to wynika $z$ powyższego cytatu - w niewoli litewskiej wówczas pozostawali ludzie niższej pozycji społecznej, $\mathrm{i}$ to oni głównie stali się beneficientami realizacji tego punktu umowy krewskiej.

\section{4}

Ostatni punkt umowy - czyli Item idem Jagal dux magnus saepedictus promittit terras suas Litvaniae et Rusiae coronae regni Poloniae perpetuo applicare, jak wspomniałem - wzbudził największe kontrowersje między historykami polskimi i litewskimi; no bo cóż miało oznaczać owo applicare? Dla jednych było to ustanie państwowości litewskiej na czas wcielenia Wielkiego Księstwa Litewskiego do Korony Polskiejej, dla innych pozostawienie jej $w$ ograniczonej formie ${ }^{33}$, a jeszcze inni kwestionują obowiązywalność postanowień aktu krewskiego. Jak wspomniałem już wyżej, nie da się zaprzeczyć wprowadzaniu w życie postanowień zawartych we wspomnianym dokumencie Jagiełly i jego braci już w 1385 r., bowiem to pod wpływem wielkiego księcia litewskiego książę mazowiecki Siemowit IV zawarł traktat $\mathrm{z}$ królową Jadwigą $\mathrm{w}$ Krakowie 12 XII 1385 r., w którym Piast ten zrzekł się dobrowolnie wszystkich ziem oderwanych od Królestwa Polskiego. Jak dowiadujemy się ze skargi synów Siemowita IV, Jagiełło, Skirgiełło i Witold wezwali do siebie ich ojca i w zamian za pewne usługi Jagiełło obiecał nadać mu omnes et singulas terras Russie, que tunc ad ipsum spectabant, nichil in eisdem pro se reservando... ${ }^{34}$. Trzeba tu zauważyć, że zarówno w akcie krewskim, jak

${ }^{31}$ Biblioteka PAN w Kórniku, rkps 203, s. 150-153.

${ }^{32}$ L. Kola n k ow ski, Dzieje Wielkiego księstwa Litewskiego za Jagiellonów, t. I: 1377-1499, Warszawa 1930, s. 60; H. Low mi á́s k i, Wcielenie Litwy do Polski w 1386 r., [w:] t e nże, Prusy-Litwa-Krzyżacy, Warszawa 1989, s. 294-402.

${ }^{33}$ Zob. J. Adamus, O prawno-państwowym stosunku Litwy do Polski, [w:] Pamiętnik VI Powszechnego Zjazdu Historyków Polskich w Wilnie, t. I, Lwów 1935, s. 174-180.

34 Articuli Vladislao regi Poloniae a ducibus Masoviae traditi Sandomiriae A. D. 1426, s. 631. 
i w nieznanym dokumencie dla Siemowita IV decyzje podejmował Jagiełło nie sam, a w towarzystwie książąt mających wplyw na politykę Wielkiego Księstwa Litewskiego. W tym kontekście można stwierdzić, że oba te akty nie były prywatnymi zobowiązaniami wielkiego księcia Jagielly, lecz umowami o charakterze państwowym.

Pierwszymi symptomami realizacji wcielenia Wielkiego Księstwa Litewskiego do Korony Królestwa Polskiego były dokumenty hołdownicze książąt z posiadanych przez siebie ziem. Zaczynają się one pojawiać od drugiej połowy 1386 r. ${ }^{35}$, a kończq̨ w maju 1393 r., gdy kniaź Fiodor Lubartowic ślubował wierność królowi Władysławowi, królowej Jadwidze oraz Koronie Królestwa Polskiego ze swego księstwa siewierskiego ${ }^{36}$. Zapewne objęcie przez Skirgiełłę księstwa kijowskiego zaledwie na miesiąc przed jego śmiercią w końcu 1394 r. było przyczyną braku stosownego dokumentu tego księcia na okoliczność zmiany stanu posiadania ${ }^{37}$. Po śmierci Skirgiełly, mimo iż zachodziły zmiany $w$ stanie posiadania książąt litewskich i ruskich, nie wystawiano dokumentów homagialnych gwarantujących ich lojalność wobec króla, królowej i Korony Królestwa Polskiego. Nie mamy więc aktu Iwana Olgimuntowica Holszańskiego, który został namiestnikiem kijowskim po śmierci Skirgiełly, ani też dokumentu kniazia Jamonta mianowanego namiestnikiem smoleńskim w $1395 \mathrm{r}$.

Nie mniej ważnym czynnikiem świadczącym za wcieleniem Wielkiego Księstwa Litewskiego do Korony Królestwa Polskiego jest tytulatura nie tylko nowego króla Polski Władysława Jagielły, ale też i królowej Jadwigi. Przypatrzmy się zatem, jak tytułowała się ta królowa po 4 III 1386 r. Brzmi owa tytulatura następująco: Heduigis Dei gracia regina Polonie princepsque Lithwanie supprema et heres Russie ${ }^{38}$. Zwracają naszą uwage szczególnie słowa regina w odniesieniu do Polski oraz princeps supprema, a nie principissa supprema w odniesieniu do Litwy. Tej tytulatury królowa Jadwiga używa

${ }^{35} \mathrm{AU}, \mathrm{nr} 15,16,17,16,19,20,21,22,23,24,25,26,27,28$.

${ }^{36} \mathrm{AU}, \mathrm{nr} 33$ i 34.

37 J. Tęgow ski, Rok 1394 w dziejach Kijowszczyzny, [w:] Pamiętnik Kijowski, t. VI: Polacy $w$ Kijowie, red. H. Stroński, Kijów 2002, s. 19-28. Innego zdania jest J. Nik odem (Charakter rzqdów Skirgielly $i$ Witolda na Litwie w latach 1392-1394), Lituano-Slavica Posnaniensia 2005, t. XI, s. 153-163), który twierdzi, iż Skirgielło ani przez moment nie panował w Kijowie.

${ }^{38}$ Zbiór dokumentów malopolskich [cyt. dalej: ZDM], cz. 8, wyd. I. Sułkowska-Kurasiowa, S. Kuraś, Wrocław 1975, nr 2539, s. 361 (19 III 1387 r.), nr 2542a, s. 366-367; Kodeks dyplomatyczny miasta Krakowa, cz. 1, wyd. F. Piekosiński, Kraków 1879, nr 64 A, s. 77-78; Kodeks dyplomatyczny katedry krakowskiej [cyt. dalej: KDKK], cz. 2, wyd. F. Piekosiński, Kraków 1883, nr 387 i 388, s. 170-172; Zbiór dokumentów katedry $i$ diecezji krakowskiej [cyt. dalej: ZDKK], cz. I: 1063-1415, wyd. S. Kuraś, Lublin 1965, nr 99, s. 161 i nr 111, s. 191; Dokumenty polskie z archiwów dawnego Królestwa Wegier, t. I, wyd. S. A. Sroka, Kraków 1998, nr 24, 25, s. 32-33 i nr 28, s. 37 (28 II 1395 r.). 
w dokumentach do końca 1394, a nawet jeszcze do początku 1395 r., po czym następuje zaniechanie elementów litewsko-ruskich na rzecz węgierskich: Heduigis Dei gratia regina Poloniae et heres Hungariae regnorum etc. ${ }^{39}$ Tytulatura węgierska Jadwigi pojawiła się po zgonie Marii - siostry królowej Jadwigi, czyli po 17 maja 1395 r. $^{40}$ Polska królowa pozostała jako jedyna naturalna dziedziczka tronu węgierskiego (nie licząc Andegawenów neapolitańskich) i te pretensje do swej ojcowizny uzewnętrzniala w tytulaturze. To komplikowało sytuację Zygmunta Luksemburskiego na Węgrzech, a wiadomo, iż wladca ten nie sprzyjal rządom Jagiełly w Polsce. Monarcha ten wspierał Władyslawa Opolczyka w jego działaniach zmierzających do wyzbycia się ziemi dobrzyńskiej na rzecz zakonu krzyżackiego. Jest faktem, że mamy zbyt mało dokumentów Jadwigi z lat 1395-1399, lecz w żadnym z zachowanych aktów wystawionych przez tę monarchinię nie spotykamy już litewsko-ruskiej tytulatury. Tytulatura ta jednak użyta została w stosunku do królowej Jadwigi przez jej męża w dokumencie z 25 I 1396 r., który dotyczył oprawienia jej wiana na ziemi kujawskiej i ruskiej ${ }^{41}$. Nie spotykamy tytulatury królowej Jadwigi w żadnym $\mathrm{z}$ dokumentów $w$ formie pełnej, jak to ma miejsce w przypadku jej męża: Wladislaus Dei gratia rex Poloniae, necnon terrarum Cracoviae, Sandomiriae, Siradiae, Lanciciae, Cuiaviae, Pomeraniae, Lithuaniae princeps supremus, Russiaeque dominus et haeres ${ }^{42}$.

Zarówno holdy książąt, jak też tytulatura króla i królowej zaświadczają o chęci wypełnienia punktu umowy krewskiej dotyczącego wcielenia ziem Wielkiego Księstwa Litewskiego do Korony Królestwa Polskiego w okresie od 1385 do 1395 r. Pośrednio zaświadcza o tym przyłączenie nowo powstałej diecezji wileńskiej do metropolii gnieźnieńskiej, aczkolwiek - jak to już zauważył Władysław Abraham, a za nim Jerzy Ochmański - polski episkopat nie jest poświadczony w aktach stanowiących podwaliny Kościoła na Litwie ${ }^{43}$.

${ }^{39} \mathrm{KDKK}$, cz. 2, nr 419, s. 213 , nr 424, s. 218 , nr 430 i 431, s. 225-227; ZDKK, nr 130, s. 233; ZDM, cz. 1, Wroctaw 1962, nr 226, s. 282-283, nr 228, s. 285; ZDM, cz. 8, nr 2554, 2555, s. 378, 380; Kodeks dyplomatyczny Wielkopolski, t. III, wyd. I. Zakrzewski, Poznań 1879 , nr 1979 i 1980, s. 701-702; t. VI, wyd. A. Gąsiorowski, H. Kowalewicz, Warszawa-Poznań 1982, nr 360, s. 415 (tutaj tytulatura nieco inna: Haedvigis reginae Poloniae et cohaeredissae Hungariae).

${ }^{40}$ S. A. S rok a, Polacy na Wegrzech za panowania Zygmunta Luksemburskiego 1387-1437, Kraków 2001, s. 16-17, przyp. 7 .

${ }^{41} \mathrm{KDKK}$, cz. 2, $\mathrm{nr} 410$, s. 202-203: Hedwigis regina Polonie et heres Vngarie regnorum, Lithwanieque princeps suprema et heres Rusie.

${ }^{42}$ ZDM, cz. VI, Wroclaw 1974, nr 1527, 1530, 1541, 1544 itd.

${ }^{43}$ W. A b ra h a m, Polska a chrzest Litwy, s. 20-22; J. O ch m ań ski, Biskupstwo wileńskie..., s. 8. 
We wcześniej opublikowanym artykule zwróciłem uwage na to, że to nie ugoda ostrowska z Witoldem z sierpnia 1392 r., a śmierć Skirgiełly - brata Władysława Jagielly, miała przełomowe znaczenie w dziejach stosunków polsko-litewskich ${ }^{44}$. Książę ten zmarł tuż przed świętami Bożego Narodzenia 1394 r., po czym dopiero Witold przejąl pełną kontrolę nad całym Wielkim Księstwem Litewskim.

Nie mamy wiele autentycznych dokumentów i listów Witolda wystawionych w czasie od śmierci Skirgiełly do klęski nad Worsklą, lecz już to, czym dysponujemy, pozwoli nam wysnuć właściwe wnioski o sytuacji w Wielkim Księstwie Litewskim po śmierci Skirgiełly. Tytulaturę Witolda przed końcem 1394 r. omówiłem we wspomnianym przyczynku na łamach Zapisek Historycznych. Po ugodzie ostrowskiej przyslugiwal Witoldowi - podobnie jak Skirgielle - oprócz tytulatury ziemskiej, tytuł dux Lithuaniae. Od początku 1395 r. jednak mamy zlamanie tej zasady przez Witolda, który tytuluje się w listach do wielkiego mistrza zakonu krzyżackiego von Gotes gnaden grosfurste $z u$ Littowen $^{45}$. Jednak inaczej tytułowany jest Witold $\mathrm{w}$ dokumencie wystawionym razem $\mathrm{z}$ królem Władysławem Jagielłą dla biskupstwa wileńskiego, gdzie nazwany jest Allexander alias Witowdus eadem (tj. Dei) gracia dux Lithuanie dominusque Trocensis etc. ${ }^{46}$ Tak samo nazwal go biskup wileński Andrzej w dokumencie wystawionym w Lidzie 3 VI 1397 r. oraz kapituła wileńska $w$ dokumencie $\mathrm{z} 1$ XII $1398 \mathrm{r}^{47}$

Z czym mamy zatem do czynienia? Czy chodzi o zwykłe pomyłki kancelarii Witolda bądź kancelarii królewskiej czy biskupiej, czy też może o tworzenie przez Witolda atmosfery dla stopniowego odłączenia się od unii Litwy z Polską? Witold nie miał już w tym czasie konkurenta w postaci Skirgiełly gotowego przeciwstawić się jego usiłowaniom skupienia całej władzy na Litwie i Rusi. Strona polska chciała podtrzymywać stan stosunków z Litwą sprzed roku 1395 i traktowała Witolda jako namiestnika Jagiełły $\mathrm{z}$ dość szerokimi uprawnieniami. Ten stan cichego mocowania się Witolda i Jagiełły dostrzegał zakon krzyżacki, który pomimo dwóch ciężkich zawodów, jakich doznał od Kiejstutowica, podjąl separatystyczne negocjacje $z$ Witoldem $w$ sprawie pozyskania Żmudzi i zwolnienia z niewoli Zygmunta Kiejstutowica w 1398 r. $^{48}$

${ }^{44} \mathrm{~J} . \mathrm{T}$ e g ow ski, Zagadnienie wladzy w Wielkim Ksiestwie Litewskim w okresie między unia krewskq a zgonem Skirgielly (1385-1394), Zapiski Histor. 2001, t. 66, z. 4, s. 7-18.

${ }^{45} \mathrm{CEV}$, nr 117, s. $39-40$ (przed 24 VI 1395 r.), nr 127, s. 41, nr 140, s. 44; Liv -, Est- und Kurländisches Urkundenbuch, t. 4, wyd. G. F. Bunge, Reval 1859, nr 1422, s. 130, nr 1469 i 1470 , s. 201-209.

${ }^{46} \mathrm{KDKW}$, nr 30, s. $51-52(20 \mathrm{~V} 1397$ r.)

${ }^{47} \mathrm{KDKW}$, nr 31, s. 52-53, nr 34, s. 60-62.

${ }^{48}$ Die Staatsverträge des Deutschen Ordens in Preussen im 15. Jahrhundert, t. I: 1398-1437, wyd. E. Weise, Marburg 1970, nr 1, 2 i 3, s. 7-13. 
Ze strony polskiej pewien krok uczyniła królowa Jadwiga, domagając się $\mathrm{w}$ liście do Witolda daniny z ziem litewskich i ruskich należnej jej z racji zapisu wiennego Władysława Jagiełły. Nie znamy samego listu, lecz wiadomość o nim przekazal nam kronikarz pruski Jan $z$ Reden (Posilge) w tych oto slowach:

Item in desin cziten [tj. $\mathrm{w} 1398 \mathrm{r}$.$] hatte dy konigynne von Polan geschrebin$ eynen briff an Wyttowde, und schreibyn erin liben bruder und bat yn, das her ym sulde lassin gedechtig sin, wie der irluchte furste, ir herre, der koning von Polan, ir dy lant czu Russin und Littowen bescheydin hette in der morgingabe und gegebin uff $d y$ cziit, als sy yn genomen hette czu eyme herren; und bat $y n$, das her tete als ir liber bruderund getruwer, das her ir nemeliche czinse nemelicher landen beschide, die ir jerlichin wordin gegebin und vorguldin ${ }^{49}$.

Wydarzenie to miało miejsce $w$ momencie, gdy pozycja Witolda na Litwie była wyjątkowo silna, a tendencje separatystyczne Litwinów dostatecznie poparte ich sukcesami na wschodnich granicach, podsycone zostały umiejętnie przez dyplomację krzyżacką. Żądanie Jadwigi upublicznił Witold, podgrzewając tym wśród Litwinów nastroje przeciwne unii z Polską, by $w$ rezultacie umożliwić własną koronację. W czasie rokowań z przedstawicielami zakonu krzyżackiego na wyspie Salin - wedle relacji kronikarza pruskiego - doszlo do elekcji Witolda na króla Litwinów i Rusinów ${ }^{50}$. W historiografii pojawił się pogląd, że te separatystyczne tendencje Litwinów mial wspierać sam król Władysław Jagiełło ${ }^{51}$. Jest to raczej mało prawdopodobne.

Elekcja Witolda na suwerennego władce Litwy i zawarcie przezeń separatystycznego układu z państwem zakonu krzyżackiego w Prusach nie wywolały w Polsce spodziewanego przez Krzyżaków ostatecznego rozłamu Wielkiego Księstwa Litewskiego i Korony Królestwa Polskiego, aczkolwiek nie mamy pewności, czy nie doszłoby do tego w przypadku pomyślnego rezultatu bitwy nad Worsklą w sierpniu 1399 r.

Układ Saliński Witolda $\mathrm{z}$ zakonem krzyżackim okazał się jednak dla Krzyżaków trudny do skonsumowania, bowiem koncesje udzielone przez Witolda nie miały mocy prawnej bez akceptacji ze strony Jagiełly. Ta akceptacja nastąpiła w zamian za zgodę na wykup ziemi dobrzyńskiej w traktacie raciąskim $^{52}$.

${ }^{49}$ Scriptores rerum Prussicarum [cyt. dalej: SRPr.], t. 3, Leipzig 1866, s. 219.

so Ibidem, s. 224.

${ }^{51}$ A. Proch a ska, Dzieje Witolda w. księcia Litwy, Wilno 1914, s. 92; K. M yśliński, Król Wladyslaw Jagiello a unia horodelska - przyczynek do charakterystyki wladcy, LithuanoSlavica Posnaniensia 1997, Studia Historica VII, s. 121; Z. Ki a u pa, J. K i a u pienè, A. Kuncevičius, The history of Lithuania before 1795, Vinius 2000, s. 135.

${ }^{52}$ Die Staatsverträge des Deutschen Ordens..., t. 1, nr 22-29, s. 31-39. 
Bez wątpienia klęska w bitwie $\mathrm{z}$ Tatarami nad rzeką Worsklą, gdzie legł na placu boju cały zastęp książąt i kwiat rycerstwa, w tym wielu Polaków, miała znaczący wpływ na utrzymanie związku Wielkiego Księstwa Litewskiego z Królestwem Polskim, bowiem uświadomiła Witoldowi i Litwinom, iż związek obu państw jest koniecznością. Należało jednak przystosować warunki unii obu państw do realnych możliwości, co zdolano uczynić w traktatach wileńsko-radomskich, gdzie aspiracje wielkoksiążęce Witolda zostały zatwierdzone przez króla Władysława Jagiełłę i panów polskich ${ }^{53}$.

Rekapitulując powyższe uwagi, możemy z całą pewnością stwierdzić, że w okresie od 1385 do 1399 r. próbowano wprowadzać w życie postanowienia dokumentu krewskiego i niektóre $\mathrm{z}$ nich całkowicie zrealizowano, jak np. chrzest Litwinów czy uwolnienie jeńców chrześcijańskich. Jednakże warunek spłaty 200 tys. florenów Wilhelmowi Habsburgowi nie został wypełniony $\mathrm{z}$ powodu braku zgody na to księcia austriackiego. Akt krewski nie byl prywatnym dokumentem wielkiego księcia litewskiego, bowiem małżeństwo wielkiego księcia Jagiełly $\mathrm{z}$ królową Jadwigą nie było aktem o charakterze prywatnym, co dodatkowo poświadcza fakt poręczenia tego dokumentu przez książąt litewskich Skirgiełłę, Korybuta, Witolda i Lingwena, którzy przywiesili do dokumentu swoje pieczęcie. Małżeństwo to rodziło skutek w postaci unii obu państw.

Wejście $w$ życie samej unii nastąpiło nie w chwili wystawiania dokumentu w Krewie, aczkolwiek Jagiełło zaczął realizować swe zobowiązania tuż po wystawieniu dokumentu krewskiego. Dopiero w momencie zawarcia małżeństwa z Jadwigą, które poprzedziła preelekcja na przyszlego króla ${ }^{54}$, można mówić o początku unii Polski z Litwą. Dopiero wówczas można było przystąpić do uroczystej koronacji wielkiego księcia Jagiełły na króla Polski oraz realizowania planu nakreślonego aktem krewskim.

Najtrudniejszym do zrealizowania, ale też i do ocenienia przez historyków, był program wcielenia Wielkiego Księstwa Litewskiego do Korony Królestwa Polskiego (nie do samego Królestwa Polskiego!), który był realizowany

${ }^{53} \mathrm{AU}, \mathrm{nr} 37,39$ i 44.

${ }^{54}$ Zapowiedź elekcji mającej się odbyć i w Lublinie 2 II 1386 r. mamy w dokumencie wystawionym przez posłów polskich w Wołkowysku 11 I 1386 r. (AU, nr 2, s. 3-4). O odbytej elekcji wspomina Jagiełło w dokumencie wystawionym 18 II 1386 r. (KDW, t. III, nr 1843, s. 573): ...quod piis affectibus, quibus nos prelati, barones totaque communitas procerum et nobilium divina ipsis inspirante gracia in tutorem et gubernatorem benivole et gratanter elegerunt et susceperunt, congruas vices rependere et retribuere cupientes, ipsis libertates infrascriptas, in articulis sequentibus contentas, tenore presencium concedimus et donamus per nos et successores nostros perpetuis temporibus observandas. 
z różnym skutkiem w poszczególnych fazach. $Z$ całą pewnością państwowość litewska w latach 1386-1394 miala charakter ograniczony, po czym Witold podjął próby jej reaktywowania w latach $1395-1399$, co powiodło się jedynie częściowo. W omawianym okresie nie odnotowano sporów polsko-litewskich na gruncie prawnym, toteż nie było potrzeby dowodzić stronie litewskiej, że godziła się na warunek inkorporacji ziem litewskich i ruskich do Korony Królestwa Polskiego, a więc nie wyciągano samego dokumentu z archiwum kapituły krakowskiej, co nie znaczy, że nie znano jego zawartości.

Nowe uregulowanie w sprawie unii obu państw w Wilnie i Radomiu w momencie, gdy ustała jej bezpośrednia przyczyna - małżeństwo Jagiełly z Jadwiga - musiało uwzględniać nie tylko ambicje osobiste Witolda, lecz razem $\mathrm{z}$ nimi ograniczoną samodzielność państwową Wielkiego Księstwa Litewskiego pod rządami Witolda. Małżeństwo Jagielły z Anną Cylejską, które jest bezpośrednio związane z tzw. unią wileńsko-radomską, umożliwiło kontynuowanie unii na gruncie personalnym, bowiem Anna jako wnuczka Kazimierza Wielkiego wnosiła swe prawa dziedziczki naturalnej Królestwa Polskiego, a tym samym przenosila te prawa na Wladyslawa Jagiełlę ${ }^{55}$.

W momencie wejścia $w$ życie nowych uregulowań w sprawie stosunku obu państw w Wilnie i Radomiu postanowienia aktu krewskiego przestaly być aktualne.

ss Joanni Dlugossi Annales seu Cronicae, lib. X, s. 236-237; Z. W d ow is ze w sk i, Genealogia Jagiellonów, Warszawa 1968, s. 37; F. S i k o r a, W sprawie malżeństwa Wladyslawa Jagielly z Annq Cylejska, [w:] Personae Colligationes Facta, Torun 1991, s. 93-103; J. T ęgowsk i, Pierwsze pokolenia Giedyminowiczów, Poznań-Wrocław 1999, s. 127-128. O tym, że prawa naturalne były w owym czasie szanowane, świadczy dokument rajców krakowskich (KDMK, cz. 1, nr 64B) oraz używanie tytulatury węgierskiej przez królową Jadwigę po śmierci jej siostry Marii. 